\title{
THE USAGE OF SCORING MODELS TO EVALUATE THE RISK OF BANKRUPTCY ON THE EXAMPLE OF COMPANIES FROM THE TRANSPORT SECTOR
}

The process of designing and implementing scoring systems as effective research tools, used to evaluate the risk of bankruptcy of companies is presented in this publication. An attempt has been made to use scoring models in practice to predict bankruptcy of the Polish companies from the logistics sector. The main goal of the conducted research was to examine effectiveness of usage of scoring models as effective tools for bankruptcy prediction. To practically implement the scoring models the Statistica package has been used, as well as own calculating procedures in the Statistica Visual Basic programming language have been designed.

\section{INTRODUCTION}

In the last years the number of the Polish companies in danger of going bankrupt has increased. Companies from the logistics sector are also exposed to the risk of bankruptcy. As it results from an analysis of bankruptcy statistics of the Corporate Database that belongs to the EMIS information system ${ }^{2}$, in the period from January 2004 to July 2012 more than 60 new Polish companies from the logistics sector have declared bankruptcy. The causes of bankruptcy are multi-level and many-sided. The most common causes of bankruptcy on the macroeconomic level are $^{3}$ : recession in economy, recession in industry, level of unemployment, foreign currencies rates, tax levels. Sector causes of corporate crisis are: payment gridlocks, increase in competition level, influx of foreign capital. Among the internal causes of bankruptcy the most important ones are: lack of capital or other resources, incorrect company management, incorrect development strategy or lack of it, low effectiveness of administration, incorrect pricing policy, internal conflicts, etc. Bankruptcy is always a disadvantageous occurrence, mainly in the economic and social aspect, so it is very important to predict the potential threat of bankruptcy early enough.

Statistical parametric models, such as: models of linear discriminant analysis (LDA) and logit models have been used for many years to predict bankruptcy of companies. Scoring models are also used more and more often, they are successfully used to predict credit default in the credit risk management processes.

The process of designing and implementing scoring system as an effective research tool, used in company bankruptcy risk assessment has been analyzed in the publication. There has been an attempt to practically use scoring models to predict bankruptcy of Pol-

\footnotetext{
${ }^{1}$ Tomasz Pisula, PhD, Department of Quantitative Methods, Faculty of Management, Rzeszow University of Technology.

2 www.securities.com

3 T. Korol, B. Prusak, Upadłość przedsiębiorstw a wykorzystanie sztucznej inteligencji, wyd. 2, Wydawnictwo CeDeWu, Warszawa 2009, p. 44-78.
} 
ish companies from the logistics sector. The main goal of conducted empirical research was to examine the effectiveness of usage of scoring models as effective tools of bankruptcy prediction. Statistica package and own calculation procedures in the Statistica Visual Basic programming language have been developed for practical implementation of scoring models.

The article has a following structure. In chapter 2 there are presented characteristics of main research directions (including ones in Poland), concerning the issue of company bankruptcy prediction as well as discussion on theoretical aspects of scoring models usage. In chapters 3 and 4 aspects of designing the scoring systems are discussed. The main problems concerning the choice of diagnostic variables for the model are discussed, whole stage of preliminary data analysis and preliminary data preparation as well as process of model estimation and construction of result scoring table. In chapter 5 complete validation process and examination of quality of estimated scoring models are discussed. Phase of implementation of scoring models in practice is discussed in chapter 6 . This chapter presents main results of empirical research on the possibility of practical usage of scoring models to predict bankruptcy risk of Polish companies from the logistics sector. In the last 7 chapter there is a short summary of the most important practical conclusions.

\section{MODELLING OF BANKRUPTCY RISK}

The usage of statistical models in the issue of company bankruptcy prediction was started by Beaver's research. Results of his analysis were published in the work ${ }^{4}$, in which he included more than thirty years of his experience in research on financial indicators of bankrupted and healthy companies. Beaver's research is the first attempt of formal statistical approach to use financial indicators in an analysis of financial insolvency risk prediction and predicting threat of company's bankruptcy.

On the basis of Beaver's research Altman ${ }^{5}$ started the most popular group of models of company bankruptcy prediction, the so-called statistical parametric models using indicators used in financial analysis of companies and in accounting as main bankruptcy determinants. Altman's model was the first empirical research on possibility of usage of multivariate discriminative analysis for classification of companies threatened with bankruptcy.

Ohlson $^{6}$, similarly like Altman, used in his research financial indicators as bankruptcy determinants, however he used a logit model in the issue of classification of companies threatened with bankruptcy for the first time. It requires lesser amount of restrictive assumptions than Multivariate Discriminant Analysis method used by Altman.

Aziz and $\operatorname{Dar}^{7}$ included in their article a very profound summary of the main directions of research on the issue of company bankruptcy prediction so far. Various analytic techniques and theoretical models are used to predict companies bankruptcy. The applied prognostic models can be divided in a very general way into three main classes of models. The first class comprises of statistical models using mainly multivariate comparative sta-

4 W. H. Beaver, Financial ratios as predictors of failure, "Journal of Accounting Research" 4 (1966), p. 71-111.

5 E. I. Altman, Financial ratios, discriminant analysis and the prediction of corporate bankruptcy, "Journal of Finance", 23/4 (1968), p. 589-609.

6 J. Ohlson, Financial ratios and the probabilistic prediction of bankruptcy, "Journal of Accounting Research", 18/4 (1980), p. 109-131.

7 M. A. Aziz, H. A. Dar, Predicting corporate bankruptcy: Where we stand?, "Corporate Governance" 6/1 (2006), p. 18-33. 
tistical analysis method. Dominant role in this class is played by models using: Multivariate Discriminant Analysis, linear probability models, logit and probit models. The second class comprises of models and methods using artificial intelligence and expert systems. To this group of methods of company's bankruptcy prediction belong mainly methods using following theories: Decision Trees, Neural Networks, Genetic Algorithms or Rough Sets theory. Theoretical models create the third group of models. They are based on various types of theories and theoretical basis, analyzing these factors which force company bankruptcy. This trend of research includes methods using mainly: Entropy theory and Balance Sheet Decomposition Measure (BSDM), Gambler's Ruin theory, cash management theory or Credit Risk Theories.

In their work Aziz and Dar analysed almost 90 publications from 1968-2003, concerning theoretical and practical aspects of company bankruptcy prediction issue. According to these analyses the most commonly used models in this research are statistical methods (in 64\% of publications), after them in respect of frequency of occurrence is the research using artificial intelligence and expert systems (analyzed in $25 \%$ of publications), usage of theoretical models made the smallest group of all research (only 11\%) in the analyzed publications. The most frequently used models in research on company bankruptcy prediction were multivariate discriminant analysis (used in more than $30 \%$ of publications), after them logit models (in more than $20 \%$ of publications) and usage of neural networks (in $9 \%$ of publications). General average predictive effectiveness for models (cumulatively for bankrupted and healthy companies) is quite high and almost for every model (except for models using cash management theory) for which it makes only $64 \%$ of correct classification) oscillates between $81 \%$ and $94 \%$ (especially for models using ruin theory, as high as $94 \%$, for parametric models: MDA $86 \%$ and logit ones $87 \%$, and for neural networks $88 \%$.

Scoring models, which have been successfully used for many years to evaluate debt carrying capacity of bank's debtors, can be also used to predict company bankruptcy risk. Practical usage of scoring models in medicine is well known (to classify patients' incidence) or in marketing (to classify customers according to their preferences). In general, scoring models are methods of scoring affiliation of researched objects (on the example of companies) with 2 different classes (bankrupted and healthy companies) depending on the estimated probability of their affiliation with negative class (declared bankruptcy). To estimate the probability of bankruptcy, scoring models use previously discussed techniques and statistical models and non-statistical approach. For a few dozen years banks have successfully implemented the so-called scoring systems in the process of credit risk management. The detailed classification and possibility of usage of scoring methods can be found in the work ${ }^{8}$.

\section{DESIGNING A SCORING MODEL - DEFINING A SET OF DIAGNOSTIC VARIABLES AND CHOICE OF PREDICTORS}

The phase of designing scoring systems is one of the most important and the most laborious phase of designing the whole scoring system. The phase of designing scoring sys-

\footnotetext{
8 A. Matuszyk, Credit scoring, Wydawnictwo CeDeWu, Warszawa 2004, p. 64-74.
} 
tems used in company bankruptcy risk assessment includes the following actions ${ }^{9}$ : defining bankrupted and healthy companies (non-bankrupted), choice of base population (learning sample), an analysis of financial indicators and choice of correct predictors and their proper attributes (recoding of variables, grouping of attributes). It also includes choosing a proper model estimation method and ascribing attributes of predictors with proper scores, construction of the scoring table and the whole stage of model validation (evaluation of estimated model quality, analysis of prognostic characteristics of the scoring table).

Research sample included a group of 61 Polish companies from broadly defined logistics sector (according to the Polish Classification of Activity PKD), which declared bankruptcy in the period from January 2004 to July 2012. Statistics concerning bankruptcy were taken from bankruptcy database of Polish companies - Corporate Database EMIS information system (Emerging Markets Information Service) ${ }^{10}$. Statistical data was taken from financial reports from periods directly before bankruptcy or 2 years before the bankruptcy (depending from its availability). For each bankrupted company 2 healthy companies (not threatened with bankruptcy), for which financial indicators confirmed the lack of such threat, were selected as a research sample. Complete research sample included 61 bankrupted companies and 164 healthy companies. Research sample was randomly divided into 2 subsets: learning sample (including 150 healthy and 55 bankrupted companies) and test sample (including 6 bankrupted companies and 14 healthy ones). The learning sample was used to design and implement scoring systems, while the test sample was used to check how the designed system will work for new companies.

The basic information media about examined companies are financial reports. On the basis of the company's financial reports one can set as many as circa 70 various financial indicators ${ }^{11}$, which can be used in their bankruptcy risk analysis. The most commonly used indicators in a company economic analysis were used in this publication: financial liquidity, profitability, effectiveness of actions and financial structure. The following groups of financial indicators were used ${ }^{12}$ to predict bankruptcy risk for company from the logistics sector:

1. Liquidity indicators (indicators describing financial liquidity of examined companies): X1 - current liquidity: Current assets / Short-term liabilities), X2 - fast liquidity: (Current assets - Short-term prepayments and accruals-Stock) / Short-term liabilities, X3 KO/SB liquidities: (Current assets - Short-term prepayments and accruals - Short-term liabilities) / Balance sheet total, X4 - immediately due: (Current assets - Stock Short-term receivables) / Short-term liabilities.

2. Profitability indicators - indicators defining company's ability to generate profit:

X5 - profitability: profit from operational activity / Net income from sales, X6 - profitability: Net profit / (Equity capital - Net profit), X7 - return on assets (ROA)[\%]: Net profit / Balance sheet total $100 \%, \mathrm{X} 8$ - return on equity (ROE)[\%]: Net profit / Equity capital*100\%, X9 - return on sales (gross)[\%]: Gross profit / Net income from sales*100\%, X10 - return on sales (net)[\%]: Net profit / Net income from sales*100\%.

\footnotetext{
9 A. Matuszyk, Credit scoring, op. cit., p. 78-79.

${ }^{10}$ www.securities.com

${ }^{11}$ T. Korol, B. Prusak, Upadłość przedsiębiorstw..., op. cit., p. 149-152.

${ }^{12}$ B. Prusak, Nowoczesne metody prognozowania zagrożenia finansowego przedsiębiorstw, Wydawnictwo Difin, Warszawa 2005, p. 105-120.
} 
3. Indebtedness indicators (solvency) - indicators defining indebtedness of the examined companies:

$\mathrm{X}_{11}$ - general debt: (Short-term liabilities + Long-term liabilities) / Balance sheet total, $\mathrm{X}_{12}$ - debt on equity: total liabilities / Equity capital, $\mathrm{X}_{13}$ - debt: (Equity capital + Long-term liabilities) / Fixed assets, $\mathrm{X}_{14}$ - debt on assets: Short-term liabilities / Balance sheet total, $\mathrm{X}_{15}$ - debt: Gross profit / Short-term liabilities, $\mathrm{X}_{16}$ - debt: (Net profit + Depreciation) / Total liabilities, $\mathrm{X}_{17}$ - long-term debt: Long-term liabilities / Equity capital.

4. Effectiveness indicators - describing effectiveness of management and company's effectiveness of activity:

$\mathrm{X}_{18}$ - receivables turnover: Net income from sales / Short-term receivables, $\mathrm{X}_{19}-\mathrm{Net}$ income from sales / Balance sheet total, $X_{20}$ - fixed assets turnover: Net income from sales / Fixed assets, $\mathrm{X}_{21}$ - Cash Conversion cycle: Short-term receivables / Net income from sales $* 365+$ Stock/Operating costs $* 365$ - average value of short-term liabilities (without special funds and short-term financial liabilities) / Operating costs (without other operating costs)*365.

5. Other financial indicators characterizing company's asset and equity structure:

$\mathrm{X}_{22}$ - Equity capital / Balance sheet total, $\mathrm{X}_{23}$ - Fixed assets (without long-term prepayments and accruals) / Balance sheet total, $\mathrm{X}_{24}$ - Fixed assets / Current assets.

Financial condition of the examined companies is defined by dichotomous dependent variable $\mathrm{Y}$, where value $Y=1$ defines companies not threatened with bankruptcy, and $Y=0$ defines bankrupts.

Due to the fact that all financial aspects are predictors with numeric values, during the stage of preliminary data analysis one has to perform a proper discretization of their values, and recode them afterwards by setting values of a new scale according to the values of the so-called WoE indicator (Weight of Evidence) calculated by using the following formula:

$$
W_{i}=\left(\frac{n^{3} / n_{B 3}}{h^{3} / n_{B}}\right)
$$

where: $n_{i}^{N B}$ - the number of healthy companies for the $\mathrm{i}$ interval of predictor value variability, $n_{i}^{B}$ - the number of bankrupted companies for i interval of predictor value variability, $n_{N B}$ - total number of healthy companies, $n_{B}$ - total number of bankrupted companies.

WoE indicator values are a good indicator characterizing a bankruptcy profile of companies. High positive values of this indicator indicate good financial condition of the examined companies (high tendency to pay off incurred financial liabilities, which results in low bankruptcy risk), high negative values of this indicator prove high tendency not to pay off liabilities and high risk of bankruptcy.

Practice shows that constructing stable scoring models requires the percentage of bankrupts in the given category of predictor value variability higher than $5 \%$. When the percentage of bankrupts in the given category is lower than $5 \%$, there occurs a necessity to connect (group) this category with some neighbouring category. 
A vital issue when choosing proper predictors is also posed by a necessity to choose only such predictors which have the best prognostic properties in scope of separation, i.e. distinguishing between bankrupt and healthy companies. When preparing a ranking of predictors depending on their classifying power one can use in practice the following factors: Information Value (IV), Gini factor and Cramer's V factor.

Cramer's V factor is well known and often used in practice. It is a measure of dependence power between values of dichotomous dependent variable $Y$ - defining company's bankruptcy and values of the given predictor $X_{i}$. Values of this factor are contained in interval from 0 to 1 . The higher the factor's values, the better classifying characteristics the examined predictor possesses.

IV factor - information value of predictor is less known and it is expressed by the formula:

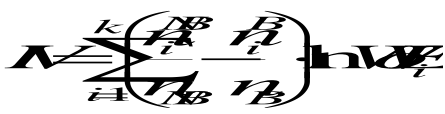

where: $k$ - number of attributes (variability intervals) of the examined predictor.

The higher the values of IV factor, the higher the predictive power of the examined predictor (or the whole scoring model) in scope of differentiation between healthy and bankrupted companies. It is assumed that IV values above 0.3 point out to a strong predictive power, while values below 0.02 show complete lack of such predictive power.

Gini factor is based on Lorenz curve factor (for the so-called ROC curve - Receiver Operating Characteristic) and it expresses a ratio of given fields on the graph of ROC curve (see fig. 1) which is expressed by the formula:

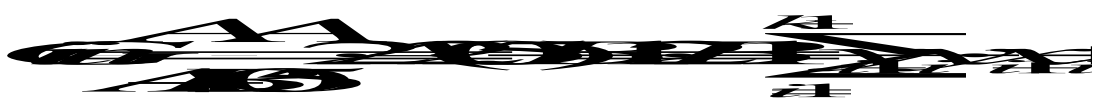

where: $y_{i}=\sum_{j=1}^{i} \frac{n_{j}^{B}}{n_{B}}$ - cumulated percent of bankrupts, for $\mathrm{i}$ attribute value of diagnostic variable, $x_{i}=\sum_{j=1}^{i} \frac{n_{j}^{N B}}{n_{N B}}$ - cumulated percent of healthy companies.

Dashed line on the ROC graph (fig. 1) represents a case, when values of the examined predictor do not have any predictive power (completely random classification of healthy and bankrupted companies). The triangle with a side of 1 makes the ideal case, when predictor has a perfect ability of distinguishing bankrupts and healthy companies. Of course, the closer the ROC curve is to the ideal one, the higher the value of the Gini factor and the better prognostic abilities of the examined indicator. It is assumed that values of the Gini factor below 0.35 point out that predictor or the whole scoring model has lost the ability to distinguish healthy and bankrupted companies.

B area lying over the ROC curve in the formula (3) is calculated as a sum of proper areas of trapezoids with height of $y_{i+1}-y_{i}$ and bases $x_{i+1}$ and $x_{i}$. 
Fig. 1. ROC curve and interpretation of Gini factor $=0.77$ for financial liquidity factor $\mathrm{X}_{3}$

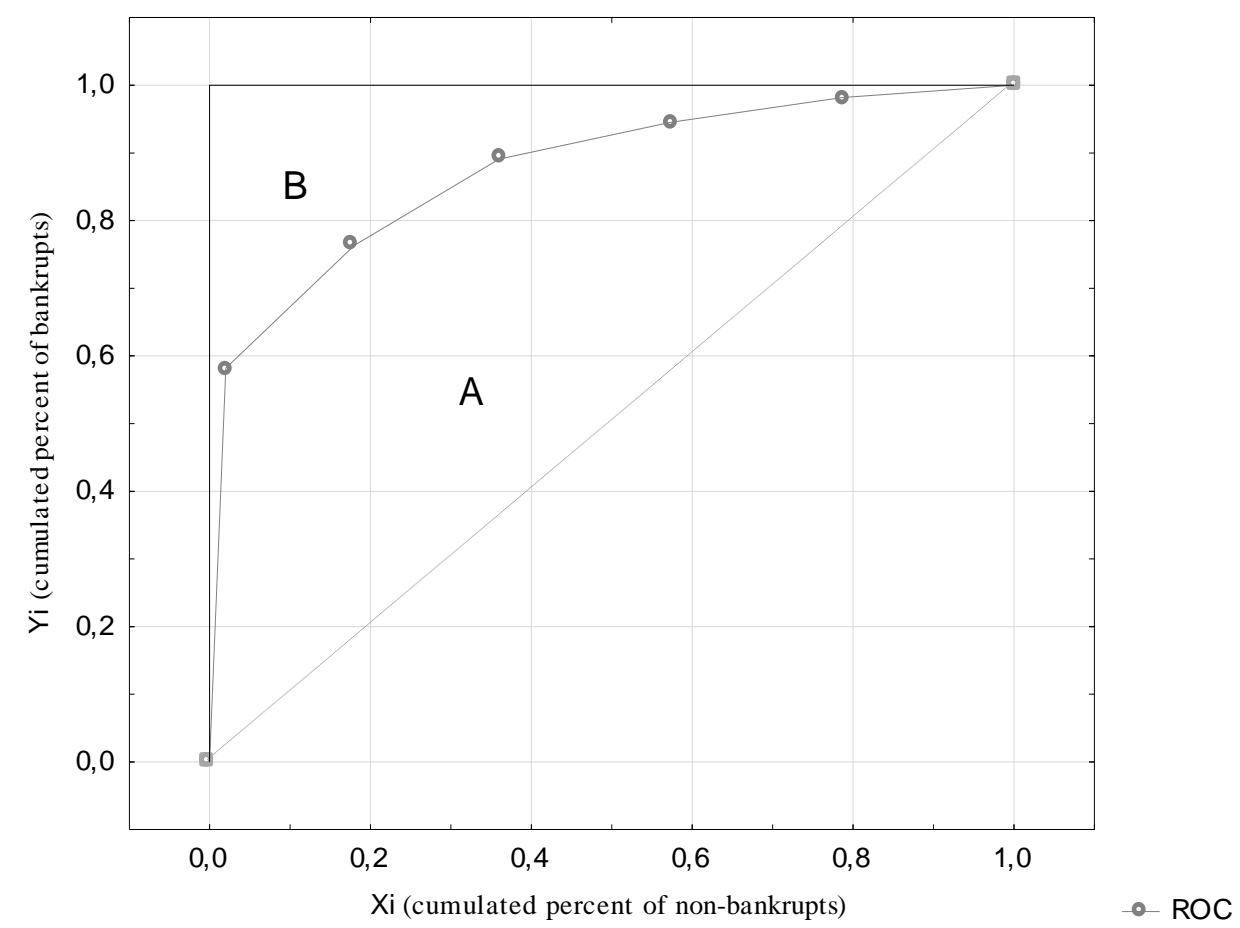

Source: own study.

Table (see table 1) presents a ranking of preliminary chosen financial indicators, which will be used to design scoring systems, which have been arranged on the basis of IV factor values. In the further analysis only 20 indicators will be taken into account, for which all predictive quality factors have values higher than 0.1 (average or high indicator predictive power).

The problem of dimension reduction of predictors used to predict bankruptcy risk with use of scoring models poses a separate issue. Some financial indicators may duplicate information entered into the model, so the number of used predictors can be reduced to the most vital representatives only. In order to do that one can use known exploration techniques of multidimensional statistical analysis, such as for example the factor analysis: analysis of the main components or analysis of the main factors. 
Table 1. Ranking of predictors in respect of their predictive power in scope of distinguishing good and bad credits depending on the value of the IV information value factor, calculated on the basis of data for the learning sample

\begin{tabular}{|c|c|c|c|c|c|c|c|}
\hline \multirow{2}{*}{ Predictor } & \multicolumn{3}{|c|}{ Factor } & \multirow{2}{*}{ Predictor } & \multicolumn{3}{|c|}{ Factor } \\
\hline & IV & Cramer's V & Gini & & IV & Cramer's V & Gini \\
\hline $\mathrm{X}_{22}$ & 2.71 & 0.7 & 0.79 & $X_{16}$ & 1.27 & 0.61 & 0.73 \\
\hline $\mathrm{X}_{13}$ & 2.45 & 0.68 & 0.73 & $\mathrm{X}_{10}$ & 1.25 & 0.53 & 0.62 \\
\hline $\mathrm{X}_{3}$ & 2.33 & 0.7 & 0.77 & $\mathrm{X}_{15}$ & 1.22 & 0.56 & 0.66 \\
\hline $\mathrm{X}_{2}$ & 2.15 & 0.63 & 0.74 & $\mathrm{X}_{21}$ & 1.19 & 0.53 & 0.59 \\
\hline$X_{12}$ & 2.12 & 0.69 & 0.16 & $\mathrm{X}_{6}$ & 0.91 & 0.48 & 0.36 \\
\hline $\mathrm{X}_{11}$ & 1.93 & 0.65 & 0.76 & $\mathrm{X}_{5}$ & 0.88 & 0.46 & 0.56 \\
\hline $\mathrm{X}_{9}$ & 1.6 & 0.53 & 0.63 & $\mathrm{X}_{18}$ & 0.42 & 0.26 & 0.13 \\
\hline $\mathrm{X}_{14}$ & 1.58 & 0.6 & 0.72 & $X_{17}$ & 0.37 & 0.34 & 0.07 \\
\hline $\mathrm{X}_{1}$ & 1.44 & 0.64 & 0.76 & $\mathrm{X}_{20}$ & 0.28 & 0.22 & 0.09 \\
\hline $\mathrm{X}_{4}$ & 1.43 & 0.59 & 0.72 & $\mathrm{X}_{19}$ & 0.23 & 0.2 & 0.15 \\
\hline $\mathrm{X}_{8}$ & 1.33 & 0.48 & 0.14 & $X_{23}$ & 0.06 & 0.11 & 0.01 \\
\hline $\mathrm{X}_{7}$ & 1.32 & 0.53 & 0.59 & $\mathrm{X}_{24}$ & 0.05 & 0.1 & 0.01 \\
\hline
\end{tabular}

Source: own study.

Table (table 2) presents values of factor loadings gained by means of factor analysis method with usage of main components method as a method of factor extracting. When extracting factors a minimal threshold for own values of 1 has been assumed as well as maximal number of determined factors not higher than 7. The standardized Varimax method (maximisation of variance of standardized factor loadings for each factor) was used as a method of factor loadings rotation. Value of 0.7 was used as a limit value of factor loadings (used to separate variable representatives within the given factor).

According to the conducted factor analysis, for 24 analyzed indicators one can separate 7 groups of strong correlation within the given group and weak correlation between groups, for which percentage of explained variance (explained variability) amounts almost up to $88 \%$. The indicator groups are: $X_{7}, X_{8}, X_{15}, X_{16}, X_{18}, X_{19}, X_{3}, X_{11}, X_{14}, X_{22}$, $X_{1}, X_{2}, X_{4}, X_{5}, X_{9}, X_{10}, X_{12}, X_{17}, X_{23}, X_{24}, X_{13}$.

One representative with the best ability to distinguish between healthy companies and bankrupts was chosen from each indicator group (see quality indicators table 1). Finally, 
The usage of scoring models to evaluate the risk...

there were 6 indicators chosen: $X_{1}, X_{7}, X_{10}, X_{12}, X_{13}, X_{24}$, which will be used as one of the predictor variants in analyzed scoring models.

Table 2. Factor loadings for 7 factors separated by means of main components method for 24 chosen financial indicators, calculated on the basis of data for learning sample

\begin{tabular}{|c|c|c|c|c|c|c|c|}
\hline \multirow{2}{*}{ Predictor } & \multicolumn{7}{|c|}{ Factor } \\
\hline & 1 & 2 & 3 & 4 & 5 & 6 & 7 \\
\hline $\mathbf{X}_{1}$ & 0.009 & 0.044 & -0.998 & 0.027 & \begin{tabular}{|l|}
-0.004 \\
\end{tabular} & 0.015 & -0.008 \\
\hline$X_{2}$ & 0.009 & 0.042 & -0.998 & 0.027 & -0.004 & 0.015 & -0.006 \\
\hline $\mathbf{X}_{3}$ & 0.018 & 0.941 & -0.039 & 0.203 & 0.012 & 0.117 & 0.101 \\
\hline $\mathbf{X}_{4}$ & 0.007 & 0.039 & -0.999 & 0.026 & -0.004 & 0.005 & -0.009 \\
\hline $\mathbf{X}_{5}$ & 0.044 & 0.083 & 0.002 & 0.952 & -0.060 & 0.037 & 0.015 \\
\hline$X_{6}$ & -0.019 & 0.139 & 0.008 & 0.443 & 0.090 & 0.028 & 0.099 \\
\hline $\mathbf{X}_{7}$ & 0.991 & 0.069 & 0.014 & 0.027 & 0.020 & -0.009 & 0.035 \\
\hline $\mathbf{X}_{8}$ & 0.886 & -0.008 & 0.014 & 0.073 & \begin{tabular}{|l|}
-0.161 \\
\end{tabular} & 0.075 & 0.032 \\
\hline$X_{9}$ & 0.047 & 0.137 & -0.057 & 0.964 & -0.096 & 0.093 & -0.021 \\
\hline $\mathbf{X}_{10}$ & 0.043 & 0.133 & -0.050 & 0.964 & -0.087 & 0.102 & -0.012 \\
\hline$X_{11}$ & -0.018 & -0.962 & 0.038 & -0.156 & 0.010 & 0.129 & -0.050 \\
\hline$X_{12}$ & -0.013 & -0.013 & 0.011 & -0.002 & 0.931 & 0.050 & 0.008 \\
\hline $\mathbf{X}_{13}$ & -0.034 & 0.444 & 0.014 & 0.086 & -0.002 & 0.117 & 0.768 \\
\hline $\mathrm{X}_{14}$ & \begin{tabular}{|l|}
-0.013 \\
\end{tabular} & -0.955 & 0.034 & -0.149 & -0.010 & 0.203 & -0.031 \\
\hline $\mathbf{X}_{15}$ & 0.994 & 0.016 & -0.018 & 0.021 & 0.017 & -0.006 & 0.016 \\
\hline$X_{16}$ & 0.991 & 0.019 & -0.080 & 0.019 & 0.017 & -0.011 & 0.015 \\
\hline$X_{17}$ & -0.026 & 0.013 & -0.001 & -0.078 & 0.938 & -0.063 & 0.001 \\
\hline $\mathrm{X}_{18}$ & 0.994 & 0.013 & 0.014 & -0.003 & 0.017 & -0.025 & 0.013 \\
\hline$X_{19}$ & 0.994 & -0.003 & 0.015 & -0.009 & 0.018 & 0.007 & 0.020 \\
\hline $\mathbf{X}_{20}$ & 0.530 & -0.069 & 0.017 & -0.032 & 0.022 & 0.192 & 0.609 \\
\hline $\mathbf{X}_{21}$ & 0.034 & 0.405 & -0.008 & -0.211 & 0.006 & 0.328 & -0.403 \\
\hline $\mathbf{X}_{22}$ & 0.025 & 0.971 & -0.040 & 0.147 & -0.012 & -0.091 & 0.038 \\
\hline $\mathbf{X}_{23}$ & -0.007 & 0.155 & 0.000 & -0.113 & -0.011 & -0.878 & -0.163 \\
\hline $\mathbf{X}_{24}$ & -0.028 & 0.063 & 0.029 & -0.143 & 0.023 & -0.872 & 0.019 \\
\hline $\begin{array}{c}\text { Own values } \\
\text { explained } \\
\text { variance }\end{array}$ & 6.01 & 4.13 & 3.01 & 3.17 & 1.8 & 1.8 & 1.18 \\
\hline Share [\%] & $25[\%]$ & 17.2[\%] & $12.5[\%]$ & 13.2[\%] & $7.5[\%]$ & $7.5[\%]$ & $4.9[\%]$ \\
\hline
\end{tabular}

Source: own study.

\section{ESTIMATION OF SCORING MODEL - CONSTRUCTION OF A SCORING TABLE}

The key role in scoring models is played by estimations of probability of affiliation with the negative class $p_{B}=P(Y=0)$ (company's bankruptcy) and with positive class $p_{N B}=P(Y=1)=1-p_{B}$ (company is a healthy company). 
Bankruptcy risk evaluation (so-called scoring) for examined companies is performed by using linear scaling, expressing linear interrelation between scoring and the so-called Odds ratio (it is a proportion of probability of company's affiliation with healthy companies' class in relation to the bankrupted ones) ${ }^{13}$ :

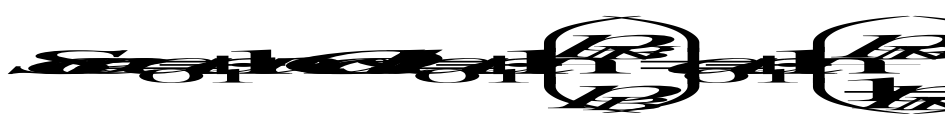

To calculate scoring we introduce also pdo parameter, defining at how many scoring points occurs double increase in chance of affiliation with healthy company class. It is expressed by the following formula:

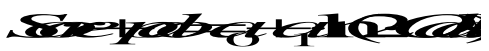

After solving a system of equations (4) and (5) one receives formulas to estimate parameters $\mathrm{a}_{0}$ and $\mathrm{a}_{1}$ :

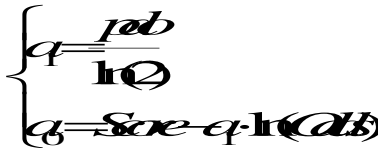

In calculations it was assumed that when score $=600$ points there is a 50:1 chance (Odds $=50)$ that the examined company will not be threatened with bankruptcy and that at every $p d o=20$ points this chance is doubled what gave estimations for parameters: $a_{0}=487,12$ and $a_{1}=28,85$.

To estimate the probability of bankruptcy one can use various statistical methods and non-statistical approach. The most commonly used statistical methods are: multivariate discriminant analysis, linear regression, logistic regression, probit regression, classification trees and the so-called methods of nearest neighbours. Out of non-statistical methods one uses mathematical programming: linear and integer ones, neural networks, genetic algorithms and expert systems ${ }^{14,15}$.

In this publication the method of logistic regression was used to estimate the probability of bankruptcy. Logistic regression model assumes that probability of company's affiliation with class of companies not threatened with bankruptcy is expressed by logistic function:

$$
p_{N B}=P(Y=1)=\frac{1}{\left(1+e^{-\left(\beta_{0}+\sum_{i=1}^{n} \beta_{i} X_{i}\right)}\right)}
$$

where: $\beta_{0}, \beta_{1}, \ldots, \beta_{n}$ - numerical factors, $X_{i}$ - financial indicators defining the company's financial condition.

\footnotetext{
${ }^{13}$ L. C., Thomas, Consumer credit models. Pricing profit and portfolios, Oxford University Press, New York 2009, p. 41-45

${ }^{14}$ A. Matuszyk, Credit..., op. cit., p. 103-142.

${ }^{15}$ M. Lasek, Metody data mining $w$ analizowaniu i prognozowaniu kondycji ekonomicznej przedsiębiorstw, Wydawnictwo Difin, Warszawa 2007, p. 26-69.
} 
The usage of scoring models to evaluate the risk...

Table 3. Scoring tables calculated on the basis of estimated logit models for various variants of diagnostic variables

\begin{tabular}{|c|c|c|c|c|c|}
\hline $\begin{array}{c}\text { Predictor } \\
\text { (vital in a model) }\end{array}$ & $\begin{array}{c}\text { Attributes } \\
\text { (value range) } \\
\text { of predictor }\end{array}$ & \begin{tabular}{|c|} 
WoE \\
$X_{i}$ \\
Scale \\
\end{tabular} & $\begin{array}{c}\text { Parameter } \\
\text { of logistic regression } \\
\beta_{i} \\
\end{array}$ & p-value & $\begin{array}{l}\text { Scoring } \\
\text { score }_{i}\end{array}$ \\
\hline \multicolumn{6}{|c|}{ version 1: all 20 indicators as diagnostic variables } \\
\hline intercept $\beta_{0}$ & & & 1.0908 & 0.00009 & \\
\hline $\mathrm{X}_{1}$ & (-inf;1.157] & -135.9 & 0.00438 & 0.02206 & 69 \\
\hline $\mathrm{X}_{1}$ & $(1.157 ;+$ inf $)$ & 213.2 & 0.00438 & 0.02206 & 113 \\
\hline $\mathrm{X}_{4}$ & $(-\inf ; 0.1134]$ & -142.2 & 0.00633 & 0.00407 & 60 \\
\hline $\mathrm{X}_{4}$ & $(0.1134 ;+$ inf $)$ & 99.2 & 0.00633 & 0.00407 & 105 \\
\hline $\mathrm{X}_{9}$ & (-inf;1.3078] & -114.6 & 0.00536 & 0.02853 & 69 \\
\hline $\mathrm{X}_{9}$ & $(1.3078 ;+$ inf $)$ & 140.4 & 0.00536 & 0.02853 & 108 \\
\hline $\mathrm{X}_{11}$ & (-inf;0.4367] & 177.9 & 0.00684 & 0.00414 & 122 \\
\hline $\mathrm{X}_{11}$ & $(0.4367 ;+$ inf $)$ & -92.5 & 0.00684 & 0.00414 & 68 \\
\hline $\mathrm{X} 16$ & (-inf;0.0847] & -160.1 & 0.00491 & 0.02603 & 64 \\
\hline $\mathrm{X} 16$ & $(0.0847 ;+$ inf $)$ & 114.1 & 0.00491 & 0.02603 & 103 \\
\hline $\mathrm{X} 23$ & (-inf;-32.923] & -143.6 & 0.00517 & 0.04159 & 65 \\
\hline $\mathrm{X} 23$ & $(-32.923 ;+$ inf $)$ & 94.3 & 0.00517 & 0.04159 & 100 \\
\hline \multicolumn{6}{|c|}{ version 2: only 6 chosen indicators as diagnostic variables } \\
\hline intercept $\beta_{0}$ & & & 1.02223 & 0.00005 & \\
\hline $\mathrm{X}_{1}$ & (-inf;1.157] & -135.9 & 0.00458 & 0.01095 & 111 \\
\hline $\mathrm{X}_{1}$ & $(1.157 ;+$ inf $)$ & 213.2 & 0.00458 & 0.01095 & 157 \\
\hline $\mathrm{X}_{10}$ & (-inf;1.0636] & -109.8 & 0.00638 & 0.00195 & 109 \\
\hline $\mathrm{X}_{10}$ & $(1.0636 ;+$ inf $)$ & 129.9 & 0.00638 & 0.00195 & 153 \\
\hline $\mathrm{X}_{13}$ & $(-$ inf; 0.8344$]$ & -167.2 & 0.00387 & 0.03290 & 110 \\
\hline $\mathrm{X}_{13}$ & $(0.8344 ;+$ inf $)$ & 121.7 & 0.00387 & 0.03290 & 143 \\
\hline $\mathrm{X}_{24}$ & (-inf;0.2475] & -182.0 & 0.00577 & 0.00025 & 99 \\
\hline $\mathrm{X}_{24}$ & $(0.2475 ;+$ inf $)$ & 138.7 & 0.00577 & 0.00025 & 152 \\
\hline
\end{tabular}

Source: own study.

To estimate probability $p_{N B}$ a general logistic regression model from Statistica package was used. In order to estimate only statistically important model parameters an algorithm of backward stepwise regression was used. Values of each predictors were preliminary discretized and their values were scaled according to the values of the Weight of Evidence (WoE) factor.

Since for the logit model a relation $\ln \left(\frac{p_{N B}}{1-p_{N B}}\right)=\beta_{0}+\sum_{i=1}^{n} \beta_{i} X_{i}$ occurs, then from interrelation (4) after transformation one gets a formula for the total score of being not 
threatened with bankruptcy (so-called bankruptcy scoring), which is a sum of scores for given attributes of each predictor:

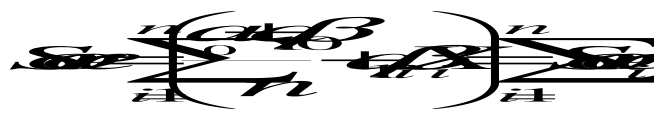

Table (see table 3) presents scoring tables for given values of predictor attributes, calculated on the basis of estimated logit models in two variants. In variant 1 set of potential predictors includes all 20 financial indicators, while in variant 2 it includes only 6 chosen financial indicators $X_{1}, X_{7}, X_{10}, X_{12}, X_{13}, X_{24}$.

\section{VALIDATION OF SCORING MODEL}

The last stage of designing a phase of a scoring model is the whole process of estimated models validation. Validation stage is based on giving the estimated models by means of proper measures and statistics an ability to differentiate between healthy and bankrupted companies. The main goal of set measures is to scrutinize how far away from each other are conditional distributions for models scoring results in population of healthy companies and bankrupts. The further away one distribution from another, the higher the values of validation factors and the better prognostic potential of the estimated scoring model (the model is assumed as better for practical implementations in scope of classification of companies in scope of the risk of their bankruptcy).

In the process of validation of scoring models in classifying applications the following factors are most commonly used: Information Value factor and Gini factor (described earlier) and Divergence factor, as well as Kolmogorov-Smirnov statistics and HosmerLemeshow statistics.

The graphic method of examining classifying power of scoring models is ROC curve and measure of area under this curve $A U R O C=0.5 \mathrm{Gini}+1$. The closer the area values are to 1 under the ROC curve, the better the prognostic ability of the evaluated model.

Kolmogorov-Smirnov statistics (KS statistics) defines maximal distance between distribution functions for scoring conditional distributions in population of healthy companies and bankrupts and is calculated using the formula ${ }^{16}$ :

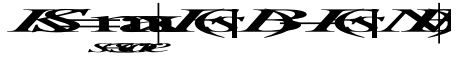

The divergence also expresses a unit of measure of distance between the scrutinized conditional distributions and it is described with the formula ${ }^{17}$ :

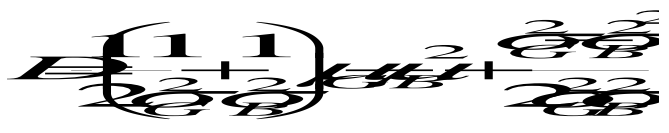

where: $\mu_{N B}=\sum_{s \in \text { score }} s \cdot f(s \mid N B)$ - average scoring in population of healthy companies, $\mu_{B}=\sum_{s \in \text { score }} s \cdot f(s \mid B)$ - average scoring in population of bankrupted companies,

\footnotetext{
${ }^{16}$ L. C., Thomas, Consumer..., op. cit., p. 111.

17 L. C., Thomas, Consumer..., op. cit., p. 108.
} 
$\sigma_{N B}^{2}=\sum_{s \in \text { score }} s-\mu_{N B}{ }^{2} \cdot f(s \mid N B), \quad \sigma_{B}^{2}=\sum_{s \in \text { score }} s-\mu_{B}{ }^{2} \cdot f(s \mid B)$ - variance of scoring respectively for the population of healthy companies and bankrupts, $f(s \mid N B), f(s \mid B)$ percentage of healthy companies and bankrupts in a given scoring category.

It is assumed that divergence should take values above 0.5 , in order for the scrutinized distributions to lay far enough from each other and the estimated scoring model to have acceptable ability to properly separate bankrupts from healthy companies.

Hosmer-Lemeshow statistics is based on Chi-squared statistics and it is calculated using the formula ${ }^{18}$ :

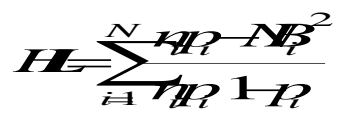

where: $p_{i}$ - average probability of being not threatened with bankruptcy for given i rating category of scoring, $N B_{i}$ - the number of healthy companies in a given rating category, $N$ - set number of rating categories, into which the range of scoring has been divided. Hosmer-Lemeshow statistics has a distribution $\chi^{2}$ with $d f=N-2$ degrees of freedom.

Table 4. Validation parameters of estimated scoring models

\begin{tabular}{|c|c|c|c|c|c|c|}
\hline $\begin{array}{c}\text { Method of estimating } \\
\text { bankruptcy probability }\end{array}$ & IV & KS & Gini & Divergence & HL & AUROC \\
\hline \multirow{3}{*}{$\begin{array}{c}\text { Model of logistics regression } \\
\text { 20 entry variables }\end{array}$} & \multicolumn{7}{|c|}{ learning sample } \\
\cline { 2 - 7 } & 3.1 & 0.79 & 0.895 & 6.3 & 15 & 0.948 \\
\cline { 2 - 7 } & \multicolumn{7}{|c|}{ test sample } \\
\cline { 2 - 7 } & 0.1 & 0.62 & 0.75 & 2.4 & 39.7 & 0.875 \\
\hline \multirow{8}{*}{$\begin{array}{c}\text { Model of logistics regression } \\
6 \text { entry variables }\end{array}$} & 3.9 & 0.76 & 0.847 & 5.5 & 16.8 & 0.924 \\
\cline { 2 - 7 } & \multicolumn{7}{|c|}{ test sample } \\
\cline { 2 - 7 } & 0.4 & 0.7 & 0.833 & 3.8 & 8.6 & 0.917 \\
\hline
\end{tabular}

Source: own study.

Table (table 4) presents validation statistics for both variants of estimated scoring models for base population (learning sample) and current population (test sample). In the case of the learning sample validation statistics for both scoring models take very similar values. Their high values prove their good classifying abilities in scope of distinguishing between companies from the logistics sector threatened and not threatened with bankruptcy and proper construction of these models on the designing stage. Model with 6 chosen diagnostic variables has better classifying characteristics for the test sample.

Figure (fig. 2) presents a graphic illustration of validations of these models with help of ROC curve for both learning and test sample.

\footnotetext{
${ }^{18}$ L. C., Thomas, Consumer..., op. cit., p. 141
} 
Fig.2. ROC curves for both variants of scoring models estimated with usage of logistics regression for learning and test samples.

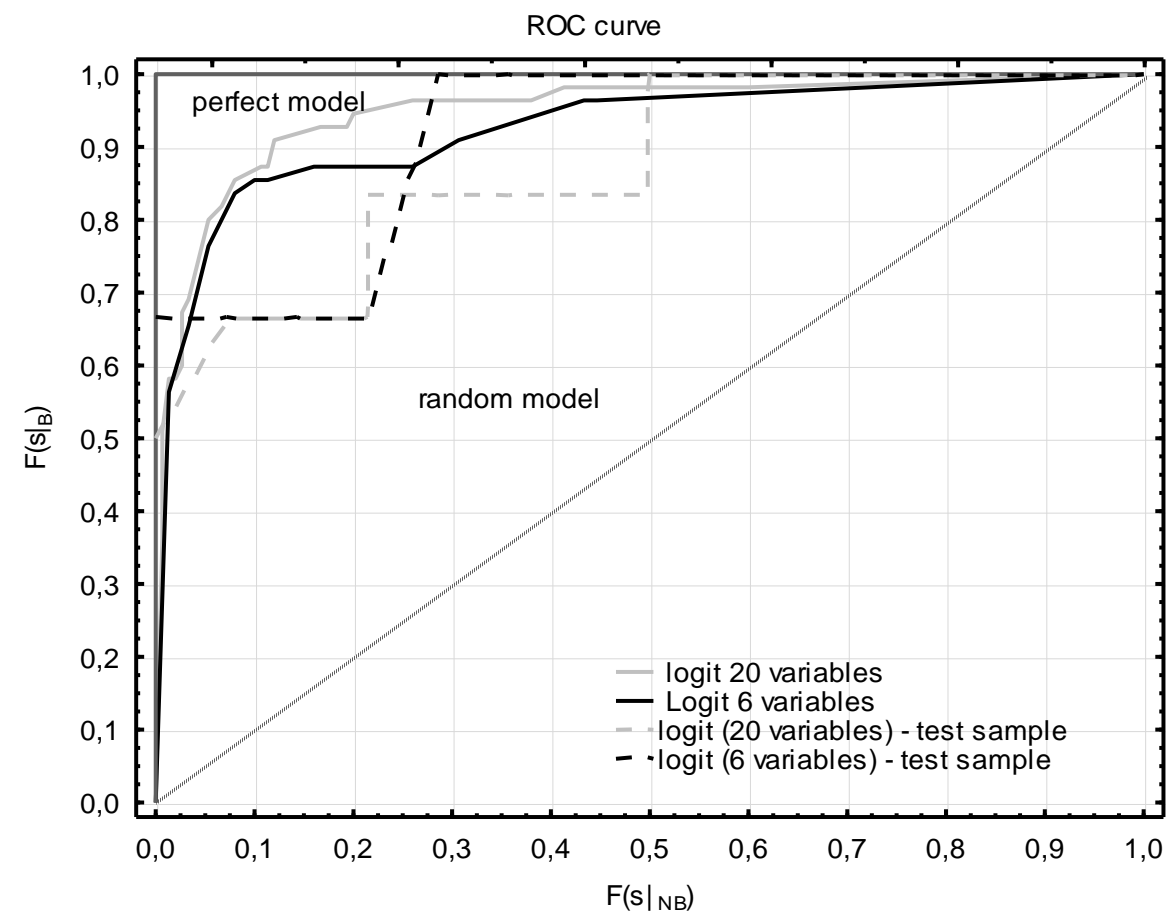

Source: own study.

\section{IMPLEMENTATION OF A SCORING MODEL}

The phase of implementation of estimated and validated scoring model comprises of a couple of stages. The first stage is setting a cut-off point. This point defines such value of scoring, below which the company is considered to be a potential bankrupt. Sometimes not one but two cut-off points are set, dividing companies into three categories: bankrupt, healthy company (not threatened with bankruptcy) and category of so-called dubious companies, for which additional research of their financial condition needs to be conducted before making a proper decision.

The next stage is conducting a training of the scoring model on learning and test samples, in order to check how correctly the model will classify companies with different cutoff points set. If effectiveness of correct classifications is satisfactory, then the scoring model can be implemented into practice.

To scrutinize classifying effectiveness of scoring models the proper classification matrix are used (see table 5). TN (True Negative) number in the table denotes the number of healthy companies properly qualified by the model. Similarly, TP (True Positive) number denotes the number of bankrupted companies properly qualified by the model. If healthy companies are classified by the model as bankrupts, then such classification error is called I-type error, and FP (False Positive) means the number of these incorrect classifications. 
Much more serious is II-type classification error, which is made, when model qualifies bankrupts as not threatened with bankruptcy, and $F N$ denotes the number of such incorrect classifications.

Table 5. Matrix of correct classification of a scoring model

\begin{tabular}{|c|c|c|}
\hline \multirow{2}{*}{$\begin{array}{c}\text { True affiliation } \\
\text { of company }\end{array}$} & \multicolumn{2}{|c|}{$\begin{array}{c}\text { Predicted affiliation } \\
\text { of company }\end{array}$} \\
\cline { 2 - 3 } & NB & B \\
\hline NB (non-bankrupt) & TN (True Negative) & $\begin{array}{c}\text { FP (False Positive) } \\
\text { I type error }\end{array}$ \\
\hline B (bankrupt) & $\begin{array}{c}\text { FN (False Negative) } \\
\text { II type error }\end{array}$ & TP (True Positive) \\
\hline
\end{tabular}

Source: own study.

I-type error, namely the percentage of incorrectly qualified healthy companies (also often denoted as: 1-specificity) is expressed with the formula:

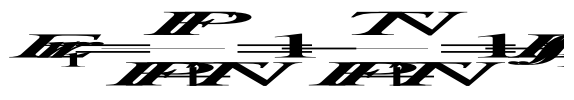

where: $\operatorname{Eff}_{1}$ (I-type effectiveness or the so-called specificity) - the percentage of correctly qualified companies as not threatened with bankruptcy.

II-type error, namely the percentage of incorrectly qualified bankrupts (often also denoted as: 1-sensitivity) is expressed with the formula:

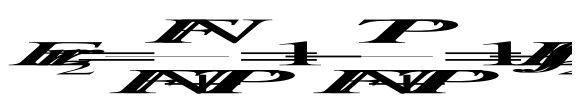

where: $\mathrm{Eff}_{2}$ (II-type effectiveness or the so-called sensitivity) - the percentage of correctly qualified bankrupted companies.

The key issue is setting the so-called optimal cut-off point, which divides companies into two classes: healthy with low bankruptcy risk and potential bankrupts with high bankruptcy risk. Assuming too low scoring as border cut-off point results in the fact that we can achieve low II-type effectiveness, namely low level of correct recognition of bad companies (bankrupts). Then the level of the so-called bad cases, namely the percentage of bad companies in a given class (which is disadvantageous especially for predicted class of companies not threatened with bankruptcy) will be also high. Assuming with utmost caution high scoring value as a cut-off point results in an increase of II-type effectiveness (which is favourable), but I-type effectiveness is reduced at the same time.

There are some ways of calculating optimal cut-off point. The first method is based on finding such value of scoring (cut-off score), for which the optimization formula is fulfilled ${ }^{19}$.

\footnotetext{
${ }_{19}$ M. H. Zweig, G. Campbell, Receiver-Operating Characteristic (ROC) plots: A fundamental evaluation tool in clinical medicine, "Clinical Chemistry" 39/4 (1993), p. 561-577.
} 


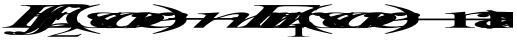

where: $m=\frac{k_{F P}}{k_{F N}} \cdot \frac{1-p_{B}}{p_{B}}, k_{F P}$ - costs of incorrect classification of healthy companies (cost of making I-type error), $k_{F N}$ - costs of incorrect classification of bankrupts (cost of making II-type error), $p_{B}$ - estimated probability of affiliation with bankrupt class (percentage of bankrupted companies in the learning sample).

Fig. 3. Optimal cut-off point $=482$ calculated as a result of optimization formula (14) for $K_{F P}: K_{F N}=1: 2$ and $p_{B}=0,268(m=1,36)$

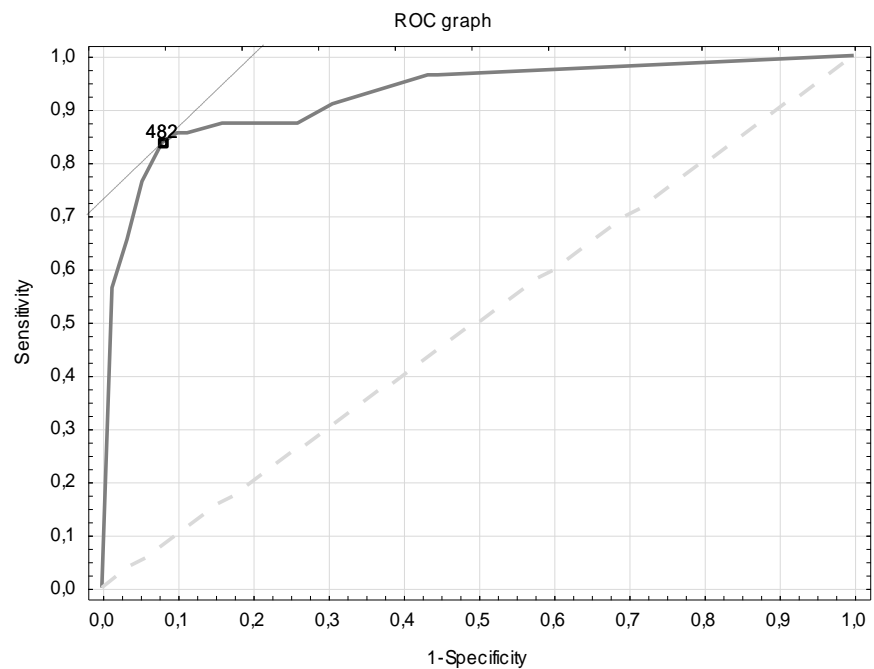

Source: own study.

Figure (fig. 3) presents calculated optimal cut-off point (equal to 482 scoring points) for the scoring model estimated with usage of logistic regression for a variant with 6 diagnostic variables. It was assumed that costs of incorrect classification for bankrupted companies are twice as high as costs of incorrect classification for healthy companies, and percentage of bankrupts in the learning sample equals $p_{B}=0,268$. In the geometric interpretation $m$ factor - is the slope of tangent to ROC curve in the set optimal cut-off point Eff $_{2}\left(\right.$ score $\left._{\text {cut }- \text { off }}\right), \operatorname{Err}_{1}\left(\right.$ score $\left._{\text {cut }- \text { off }}\right)$.

The other method is based on choosing as a cut-off point such scoring which minimizes the total cost of incorrect classifications. Optimal cut-off point is thus the solution to optimization task of the formula:

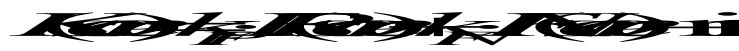

Table (see table 6) illustrates classifying effectiveness of both estimated scoring models for different cut-off points, calculated as solutions to optimization tasks (14) and (15). For the learning sample both scoring models have quite high classifying effectiveness. For bankrupted companies the percentage of correct classifications, depending on the assumed 
cut-off point varies within limits from $76 \%$ to $91 \%$. For healthy companies the percentage of correct classifications varies within limits from $88 \%$ to $95 \%$. Scoring model with 20 diagnostic variables has mainly a bit better classifying characteristics in the case of the learning sample, for both bankrupts and healthy companies. Assuming higher scoring as border cut-off point results in improvement of effectiveness of correct classifications for bankrupted companies, but it lowers the classifying effectiveness for healthy companies. However, general effectiveness, without division into categories of bankrupts and healthy companies independently from the used models and cut-off point is quite high and equals from $89 \%$ to $91 \%$.

Table 6. Matrix of proper classification for examined logit scoring models, calculated for different optimal cut-off points and for learning and test samples

\begin{tabular}{|c|c|c|c|c|c|c|c|c|c|}
\hline \multicolumn{5}{|c|}{$\begin{array}{l}\text { Logit model } \\
6 \text { variables }\end{array}$} & \multicolumn{5}{|c|}{$\begin{array}{l}\text { Logit model } \\
20 \text { variables }\end{array}$} \\
\hline \multirow{4}{*}{$\begin{array}{c}\text { Prediction } \\
\text { of bankruptcy }\end{array}$} & \multicolumn{4}{|c|}{$\begin{array}{c}\text { True } \\
\text { bankruptcy evaluation }\end{array}$} & \multirow{3}{*}{$\begin{array}{c}\text { Prediction } \\
\text { of bankruptcy }\end{array}$} & \multicolumn{4}{|c|}{$\begin{array}{c}\text { True bankruptcy } \\
\text { evaluation }\end{array}$} \\
\hline & $\mathbf{B}$ & NB & $\mathbf{B}$ & NB & & $\mathbf{B}$ & NB & $\mathbf{B}$ & NB \\
\hline & \multicolumn{2}{|c|}{ Number } & \multicolumn{2}{|c|}{$\begin{array}{c}\text { Percent } \\
{[\%]}\end{array}$} & & \multicolumn{2}{|c|}{ Number } & \multicolumn{2}{|c|}{$\begin{array}{l}\text { Percent } \\
{[\%]}\end{array}$} \\
\hline & \multicolumn{9}{|c|}{ Learning sample $n=205$} \\
\hline $\begin{array}{c}\text { B } \\
\text { (-inf.473] }\end{array}$ & 42 & 8 & 76.4 & 5.3 & $\begin{array}{c}\text { B } \\
\text { (-inf.479] }\end{array}$ & 44 & 8 & 80 & 5.3 \\
\hline $\begin{array}{c}\text { NB } \\
(473,+ \text { inf })\end{array}$ & 13 & 142 & 23.6 & 94.7 & $\begin{array}{c}\text { NB } \\
(479,+ \text { inf })\end{array}$ & 11 & 142 & 20 & 94.7 \\
\hline $\begin{array}{c}B \\
\text { (-inf.482] }\end{array}$ & 46 & 12 & 83.6 & 8 & $\begin{array}{c}\text { B } \\
\text { (-inf.514] }\end{array}$ & 50 & 18 & 90.9 & 12 \\
\hline $\begin{array}{c}\text { NB } \\
(482,+ \text { inf })\end{array}$ & 9 & 138 & 16.4 & 92 & $\begin{array}{c}\text { NB } \\
(514,+ \text { inf })\end{array}$ & 5 & 132 & 9.1 & 88 \\
\hline \multicolumn{5}{|c|}{$\begin{array}{c}\text { General effectiveness } \\
\operatorname{Eff}(473)=89.8[\%] \\
\operatorname{Eff}(482)=89.8[\%]\end{array}$} & \multicolumn{5}{|c|}{$\begin{array}{c}\text { General effectiveness } \\
\operatorname{Eff}(479)=90.7[\%] \\
\operatorname{Eff}(514)=88.8[\%]\end{array}$} \\
\hline & \multicolumn{9}{|c|}{ Test sample $\mathrm{n}=\mathbf{2 0}$} \\
\hline $\begin{array}{c}\text { B } \\
\text { (-inf.473] }\end{array}$ & 4 & 0 & 66.7 & 0 & $\begin{array}{c}\text { B } \\
\text { (-inf.479] }\end{array}$ & 4 & 3 & 66.7 & 21.4 \\
\hline $\begin{array}{c}\text { NB } \\
(473,+ \text { inf })\end{array}$ & 2 & 14 & 33.3 & 100 & $\begin{array}{c}\text { NB } \\
(479,+ \text { inf })\end{array}$ & 2 & 11 & 33.3 & 78.6 \\
\hline $\begin{array}{c}\text { B } \\
\text { (-inf.482] }\end{array}$ & 4 & 1 & 66.7 & 7.1 & $\begin{array}{c}\text { B } \\
\text { (-inf.514] }\end{array}$ & 4 & 3 & 66.7 & 21.4 \\
\hline $\begin{array}{c}\text { NB } \\
(482,+ \text { inf })\end{array}$ & 2 & 13 & 33.3 & 92.9 & $\begin{array}{c}\text { NB } \\
(514,+ \text { inf })\end{array}$ & 2 & 11 & 33.3 & 78.6 \\
\hline \multicolumn{5}{|c|}{$\begin{array}{c}\text { General effectiveness } \\
\operatorname{Eff}(473)=90[\%] \\
\operatorname{Eff}(482)=85[\%]\end{array}$} & \multicolumn{5}{|c|}{$\begin{array}{c}\text { General effectiveness } \\
\operatorname{Eff}(479)=75[\%] \\
\operatorname{Eff}(514)=75[\%] \\
\end{array}$} \\
\hline
\end{tabular}

Source: own study. 
In the case of the test sample there was a deterioration (which was to be expected) of classifying effectiveness of models. For bankrupted companies independently from model and cut-off point the percentage of correct classifications equals $67 \%$. For companies not threatened with bankruptcy the percentage of correct classification varies from $79 \%$ up to even $100 \%$. General effectiveness for a model with 20 diagnostic variables independently from cut-off point is average and amounts to 75\%, while for a model with 6 variables it is still quite high and varies from $85 \%$ to $90 \%$. It is a proof that the model with 6 diagnostic variables will perform better as a model in practical applications in predicting bankruptcy of companies from the logistics sector.

\section{SUMMARY}

Empirical research on the possibility of usage of scoring models in predicting bankruptcy of companies from logistics sector conducted in the work has shown that these types of models can be successfully used in practice to evaluate threat of bankruptcy. Broad spectrum of practical applications of scoring models and good classification abilities show that these models can be an interesting alternative for classic parameter models and non-statistical methods, such as: neural networks or decision trees.

However, it needs to be underlined that only stable and properly constructed scoring models will be helpful in predicting financial threat for companies. To make the scoring models useful in practical applications and not lose their classifying abilities one needs to monitor and update them on a regular basis. One also needs to introduce constant corrections by adding new companies to the database of bankruptcies, because only regularly monitored scoring systems may properly predict potential bankruptcy risk.

The possibility of using scoring models to conduct ex-ante predictions for new companies, not included in the research sample, makes a great application ability. Research will continue for companies from other business sectors and with usage of different risk probability estimation methods (decision trees and neural networks).

\section{LITERATURE}

[1] E. I. Altman, Financial ratios, discriminant analysis and the prediction of corporate bankruptcy, "Journal of Finance", 23/4 (1968)

[2] M. A. Aziz, H. A. Dar, Predicting corporate bankruptcy: Where we stand?, "Corporate Governance" 6/1 (2006), p. 18-33

[3] W. H. Beaver, Financial ratios as predictors of failure, "Journal of Accounting Research" 4 (1966)

[4] B. Prusak, Nowoczesne metody prognozowania zagrożenia finansowego przedsiębiorstw, Wydawnictwo Difin, Warszawa 2005

[5] T. Korol, B. Prusak, Upadłość przedsiębiorstw a wykorzystanie sztucznej inteligencji, Wydawnictwo CeDeWu, Warszawa 2009

[6] M. Lasek, Metody data mining $w$ analizowaniu i prognozowaniu kondycji ekonomicznej przedsiębiorstw, Wydawnictwo Difin, Warszawa 2007

[7] Matuszyk, Credit scoring, Wydawnictwo CeDeWu, Warszawa 2004

[8] J. Ohlson, Financial ratios and the probabilistic prediction of bankruptcy, "Journal of Accounting Research", 18/4 (1980)

[9] L. C., Thomas, Consumer credit models. Pricing profit and portfolios, Oxford University Press, New York 2009

[10] M. H. Zweig, G. Campbell, Receiver-Operating Characteristic (ROC) plots: A fundamental evaluation tool in clinical medicine, "Clinical Chemistry" 39/4 (1993). 


\section{WYKORZYSTANIE MODELI SCORINGOWYCH DO OCENY RYZYKA UPADŁOŚCI NA PRZYKŁADZIE FIRM Z SEKTORA TRANSPORTOWEGO}

W publikacji przedstawiono proces projektowania i wdrażania systemów scoringowych jako efektywnych narzędzi badawczych, wykorzystywanych w ocenie ryzyka upadłości przedsiębiorstw. Podjęto próbę praktycznego wykorzystania modeli scoringowych do prognozowania upadłości polskich przedsiębiorstw z sektora logistycznego. Głównym celem przeprowadzonych badań empirycznych było zbadanie skuteczności wykorzystania modeli scoringowych jako efektywnych narzędzi prognozowania upadłości. Do praktycznej implementacji modeli scoringowych wykorzystano pakiet Statistica oraz opracowano własne procedury obliczeniowe w języku programowania Statistica Visual Basic.

DOI: 10.7862/rz.2012.zim.27 